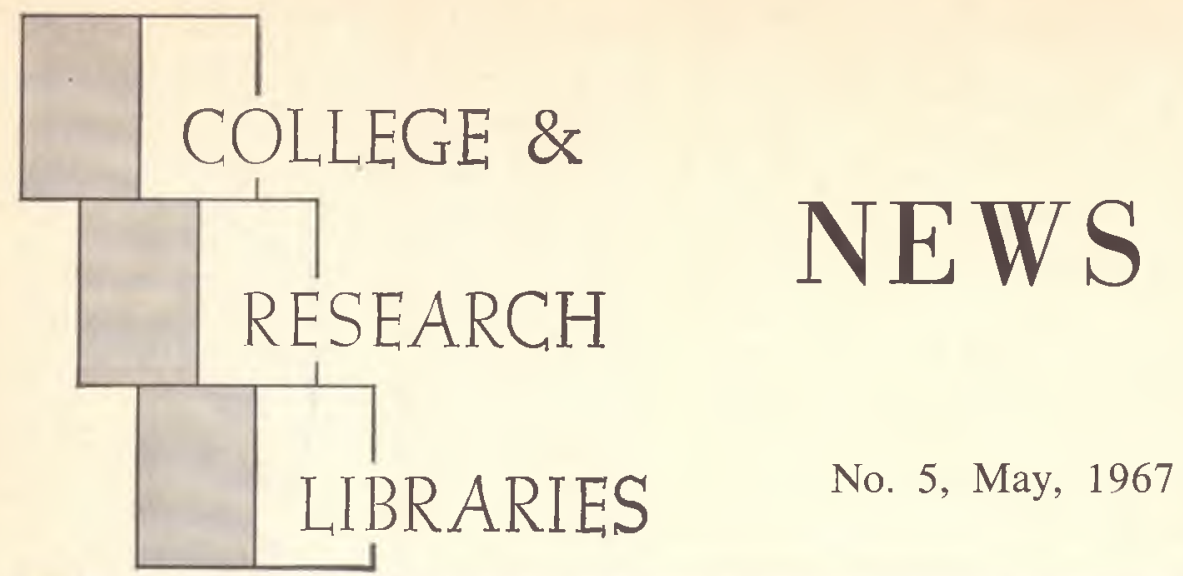

ACRL News Issue (A) of College \& Research Libraries, Vol. 28, No. 3

\title{
Proposed Addendum to Statistics For Academic Libraries
}

\section{By Marietta Chicorel}

Sources of Income. It is desirable for libraries, legislative bodies and donors, to know what the sources of income are for college and university libraries and wherever practical, the amounts of the total income obtained from each source.

There is a definite relationship between the sources and amounts of income and the work done by the library. Duration, extent, and repetition of funding have an appreciable effect on library planning.

Reporting of sources and amounts of income is of advantage both to the recipient of the funds and to the contributor of the funds. Funds which are earmarked for certain parts of the budget can better be applied when their effects on performance, production, and physical space are adequately assessed. To maintain a working balance within the operational budget, the relationship between funds allocated to library materials and to technical services and retrieval processes must be a part of the planning function of management. Therefore, the following categories are recommended for inclusion in a national data bank.

Miss Chicorel is Editor of Ulrich's International Periodicals Directory.
Recommendations

1. List sources of income according to categories described below.

2. List amounts of income according to source.

3. Indicate derived figures when primary ones are not available.

4. Report predetermined allocations of sources and/or amounts to capital and operational budgets.

5. Omit itemization by expenditure categories.

Categories for reporting sources of income:

1. Sources of income from private funds.

a. Include income from stocks, bonds, or real estate, trust funds, foundations, etc. Only funds allocated for the fiscal year to be reported should be included.

b. Contractual income.

List sources and amounts derived from privately funded agencies, industrial and business concerns, and private educational institutions.

c. Current gifts.

Report money which is given but unfunded, and money which is intended for current use in purchasing books, in services, or for other purposes. 
Include also money held in the name of an institution other than the library if allocations to the library can be reported on a fiscal basis.

2. Sources of income from public funds.

a. Include income from any level of public government, from taxes or from other funds available to such a government, including research grants and other contractual commitments.

b. Contractual income.

List sources and amounts derived from publicly funded agencies, such as the National Science Foundation, Higher Education Act Grants, from other federal research grants, or from other public educational institutions.

c. Indirect contractual income.

Report amounts and/or percentages allocated to library operations and overhead from grants received by the clientele which it serves.

\section{Other income.}

Include the sum total of income from vending machines, fines, publications, sales of discarded books, or from rental books.

If the figures supplied by the supporting institutions are not to be published, provision should be made for this request. Derived statistics should not be reported unless no others can be produced.

If percentage figures are used, however, define the total institutional budget as $100 \%$ and each of the above elements as a percentage thereof.

To reconcile the budget reports of libraries whose accounting procedures differ in placing money for books and other library materials, money which is specifically allocated for this purpose should be reported separately under "Library Materials." It can then be added to income for operation or income for capital according to local procedure.

This initial attempt at reporting on a national basis will benefit

a. future programming for libraries

b. legislative bodies in future allocation, and

c. donors who will better understand how these funds are used.

\section{BOOK MOVE AT FORT LEWIS}

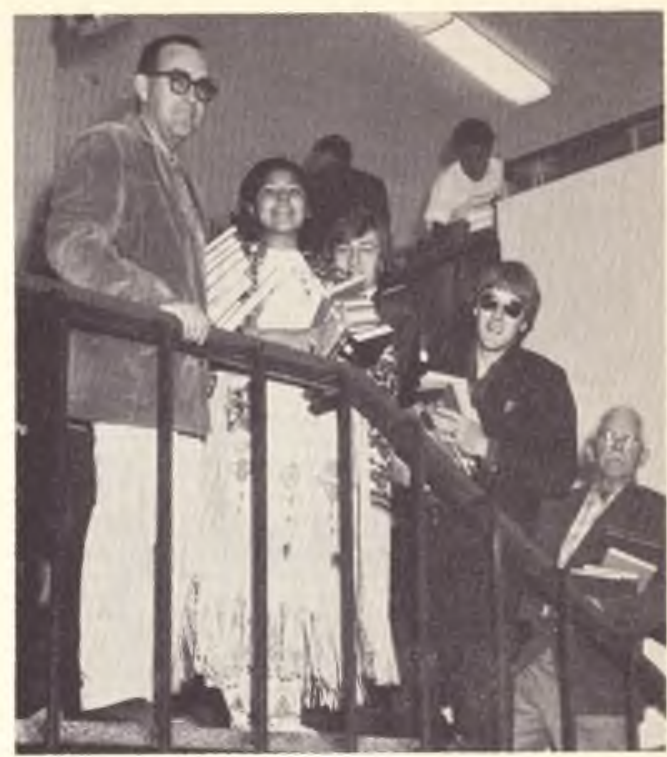

Waiting to put their loads of books on the new library's shelves-Graham Sadler, director of the Fort Lewis College library (at left), Miss Indian America, Wahleah Lujan; Chad and Jeremy, singing duo from England, and John F. Reed, president of the college.

Fort Lewis College recently completed a new million dollar library-classroom building and was faced with the problem of moving over thirty-five thousand volumes of books in the middle of a trimester without disrupting the use of the library by students any longer than necessary. Thus, at 8:30 a.m. on March 20 , over one thousand students and faculty assembled at the old library and the move began. Wahleah Lujan, a student at Fort Lewis College when she was named Miss Indian America, was on the campus ThursdaySaturday to participate in the annual Hohzoni Days (Beautiful Days) activities sponsored by the College's Shalako Indian Club. She decided to stay over and help her fellow students move the books. Chad and Jeremy, singing duo from England, who were to present a concert that evening, also decided to join the Fort Lewis students in the book move.

At noon an old fashioned "Chuck Wagon" feed was spread out for the students in front of the new library and a local band provided the music for the "Book Moving Day."

By $1: 30$ p.m., when the last of the students and faculty had had their plates filled at the Chuck Wagon, the library had been moved intact, with the books taken from the shelves in order in one building and put on the shelves in order in the new building. Formal dedication ceremonies for the library were com- 